\title{
ARTIFICIAL INTELLIGENCE AS A POTENTIAL SUBJECT OF PROPERTY AND INTELLECTUAL PROPERTY RELATIONS
}

LA INTELIGENCIA ARTIFICIAL COMO POTENCIAL SUJETO DE LA PROPIEDAD Y DE LAS RELACIONES CON LA PROPIEDAD INTELECTUAL

\author{
Kateryna Nekit * \\ Vira Tokareva** \\ Volodymyr Zubar ${ }^{* * *}$
}

\begin{abstract}
The article analyzes the possibility to provide legal capacity to artificial intelligence, which would lead to the emergence of a new subject in legal relations. The aim of the article is to reveal whether it is possible to recognize, that artificial intelligence is able to have property and intellectual property rights. To achieve this aim, dialectical, comparative, dogmatic and legal methods are used. It is noted that according to recent studies, there are more and more grounds for recognizing artificial intelligence as subjects of legal relations. Particular attention in the article is paid to the specifics of the status of artificial intelligence in property relations. The consequences of empowering artificial intelligence with the right to property are analyzed. The conclusion is drawn on the appropriateness of such an approach, since this will solve the problem of liability for damage caused by artificial intelligence. The possibility of endowing artificial intelligence with property on the basis of trust before resolving the issue of its legal personality is proposed. Modern approaches to the problem of rights to objects of

* Ph.D., Associate Professor of Civil Law Department of National University "Odesa Law Academy" (Ukraine). ORCID: 0000-0002-3540-350X katerinanekit@gmail.com

** Ph.D., Associate Professor of Civil Law Department of National University "Odesa Law Academy" (Ukraine). ORCID: 0000-0002-8409-1477 vira_tokareva@ukr.net

*** Ph.D., Associate Professor of Civil Law Department of National University "Odesa Law Academy” (Ukraine). ORCID: 0000-0003-4349-068X v.zubar@gmail.com
\end{abstract}


creativity created by artificial intelligence are considered in the article. The options for the distribution of rights to such objects are analyzed depending on the degree of human participation in their creation and on the level of complexity of the artificial intelligence that creates these objects. The general conclusion is made about the possibility to qualify artificial intelligence as a subject of legal relations, in particular, of property and intellectual property relations.

Keywords: Artificial Intelligence, Robots, Property Right, Intellectual Property Right, Creativity

Resumen: El artículo analiza la posibilidad de proporcionar capacidad jurídica a la inteligencia artificial, lo que llevaría a la aparición de un nuevo tema en las relaciones jurídicas. En concreto, analiza si es posible dar a la inteligencia artificial propiedad y derechos de propiedad intelectual. Para ello, se utilizan métodos dialécticos, comparativos, dogmáticos y legales. Cabe señalar que, según estudios recientes, hay cada vez más motivos para darle a la inteligencia artificial personalidad jurídica. Se presta especial atención en el artículo al estado actual de la inteligencia artificial en las relaciones de propiedad y se analizan las consecuencias de potenciar la inteligencia artificial con el derecho de propiedad. La conclusión se basa en la idoneidad de este enfoque, ya que esto resolverá el problema de responsabilidad por daños causados por inteligencia artificial. Se propone la posibilidad de dotar a la inteligencia artificial de bienes sobre la base de la confianza, antes de resolver el problema de su personalidad jurídica. En el artículo se consideran enfoques modernos del problema de los derechos a los objetos de creatividad creados por la inteligencia artificial. Las opciones para la distribución de derechos a dichos objetos se analizan dependiendo del grado de participación humana en su creación y del nivel de complejidad de la inteligencia artificial que crea estos objetos. La conclusión general es que cabe considerar a la inteligencia artificial como sujeto de relaciones legales, con el derecho a la propiedad y la personalidad en las relaciones jurídicas de propiedad intelectual.

Palabras clave: Inteligencia artificial, robots, derecho de propiedad, propiedad intelectual, creatividad

Sumario. I. Introduction. Ii. Analysis Of Recent Research. Iii. Subjects Of Legal Relationships: Current Status. Iv. Artificial Intelligence As A Potential Subject Of Property Relations. V. The Potential Of Artificial Intelligence To Be A Subject Of Intellectual Property Relations. VI. Conclusions. References. 


\section{INTRODUCTION}

The explosive development of information technologies, open access to information, the intensive automation of all spheres and branches of production and management, the growth of the spheres where information services are provided confirm the significant changes that are happening at the current stage of human society development. In such circumstances, it is natural for new social actors to emerge. The proliferation of autonomous mechanisms and algorithms threatens the activities of such specialists as financiers, lawyers, journalists who perform routine tasks. Repeated operations are being digitized, and at some point in time, anyone, regardless of the educational background, will be able to perform such work using a computer.

As it is stated in the White Paper on Artificial Intelligence (European Commission, 2020):

«Artificial intelligence is developing fast. It will change our lives by improving healthcare, increasing the efficiency of farming, contributing to climate change mitigation and adaptation, improving the efficiency of production systems through predictive maintenance, increasing the security of Europeans, and in many other ways that we can only begin to imagine. At the same time, artificial intelligence entails a number of potential risks, such as opaque decision-making, gender-based or other kinds of discrimination, intrusion in our private lives or being used for criminal purposes».

In such context it is essential to pay attention to solving issues connected to the legal regulation of relationships that appear in connection with the development of artificial intelligence. We should estimate the possibility of artificial intelligence to become a subject of legal relations and analyze the specifics of its status if such happens.

The consequences of such transformations in society could also affect private property relationships. The new subjects of property rights, such as artificial intelligence or robots, are likely to appear in the nearest future, which would be a result of the development of information technologies.

In the field of creativity, the software is being developed that creates soundtracks to videos that are indistinguishable from natural sounds. Robots have been created capable of reproducing handwriting indistinguishable from humans; along with artificial intelligence that wins over the world's best poker players. Therefore, the question of determining the legal status of works generated by artificial intelligence and the possibility of recognizing it as subjects of legal relations and the copyright is quite on time. 


\section{ANALYSIS OF RECENT RESEARCH}

Some issues connected to the legal status of the participants of civil relations in terms of intensive development of information technologies were investigated by Kharytonov (2017), Kharytonova (2017). A series of publications of Kokhanovska (2006), Shpenov (2011), Marushak (2011) were devoted to the study of peculiarities of the legal status of the subjects of information relations. The analysis of the legal status of the subjects of legal relations was conducted in the works of Zhilnikova (2011), Razuvayev (2007), Alekseev (1981), and others. Problems connected to the "creativity" of artificial intelligence are investigated in the works of Morkhat (2018), Pushkarev (2014), Guadamuz (2017), and others.

Some specific issues related to artificial intelligence are discussed by Kleinberg, Ludwig, Mullainathant and Sunstein (2019). The scholars have analyzed discrimination in the age of algorithms and revealed factors, which could influence on artificial intelligence in a way to make it biased. Much earlier Sunstein (2001) has also conducted another deep research in the sphere of artificial intelligence. It focuses on the possibility to engage artificial intelligence in legal reasoning. The very important research concerning the possibility to recognize artificial intelligence as an author or inventor was conducted by Pearlman (2018). However, no research on the characteristics of artificial intelligence as a potential subject of private property rights and intellectual property rights has yet been conducted. And those which are connected to the subjectivity of artificial intelligence are still debatable.

Considering this, the purpose of this study is to analyze the features of artificial intelligence as a potential subject of legal relations within the conditions of information society development and digital transformations.

\section{SUBJECTS OF LEGAL RELATIONSHIPS: CURRENT STATUS}

The present-day legal science features frequent references to the terms such as "person", "legal person", "physical person", "subject", "legal personality", "legal capacity". It should be recognized that the above categories did not emerge from within a certain legal system, but arose from a string of slowly progressing and sophisticated conceptual developments known throughout the centuries.

The term persona was common to find in the works of different authors in the Ancient Rome, however, it lacked any articulate legal meaning. Thus, in his Institutes, Gaius pointed out that... personarum haec est, quod omnes 
hominess aut liberi sunt aut serui (Saveliev \& Kofanova, 1997). But then, the Latin term persona was used to mean "part", "role", "function", "image". The said tradition to use this term without letting it have any special meaning continued until the 16th century. Even glossaries, when determining the difference between universitas and its members, did not derive an abstract category that could be contrasted with separate elements.

The French lawyer, François Duarenus (1554), who is considered to be the ancestor of the legal person unitary concept, was the first to have related the term persona both to universitates, and the elements thereof. At the end of the 16th century, the concept of persona in relation to "human" had become the target of legal analysis. Since then, the legal professionals have tried to explain the relation between a human as a real physical being, and a human as subject of law, thanks to which the term persona survived. For those who aimed to identify the concept of a person based on its material substratum, only two options remained: (i) either to maintain that a human is the only subject of law whose real existence is recognised. And thus, all other creations are regarded as "artificial"; or, (ii) to find a way to prove that such other potential "subjects" may have the real will, and thus, the right to exist.

The German lawyer, Arnold Heise (1827), was among the first to use the word combination "legal person" within the framework of a single concept of subject of law, whereby a legal person is opposed to a physical person. The ideas of Gaize were taken forward by the founder of the historic German legal school, Friedrich Karl von Savigny (1781-1854), in his work "System of the Modern Roman Law", with a specific emphasis placed on the statement that the will of the State was a critical reason for "legal persons" to ever be able to exist as "subjects of law". Legal persons as "artificial subjects" are divided into corporations and partnerships, depending on whether a personal substratum is available, or whether a more imaginary substratum exists for its intended purpose. Savigny made a point that a human being is in the middle of the non-self, and in such environment, the most important element would be coming into contact with someone similar in terms of its nature and purpose (Kutateladze \& Zubar, 2011, p. 456).

With respect to the concepts of "subject of law" and "subject of legal relationship", all positions of researchers can be summarized in two groups: some scholars consider these concepts identical (Matuzov \& Malko, 2004, p. 3), others propose to distinguish them, noting that the concept of "subject of legal relationship" is narrower than the concept of "subject of law". It is because of the fact that the subject of law is the one who just has some rights and responsibilities and may become a party to the legal relationship (but also may not participate in specific legal relationships) (Halphina, 1974, p. 114-115). The latter position is supported by Alekseev (1981), who states 
that the subject of law is one who is potentially capable of being a party to the legal relationship, and the subject of legal relationship is the real participant of these legal relations (Borysova, Spasibo-Fateyeva \& Yarotsky, 2007, p. 140). The same opinion is shared by Kharytonov, who believes that the subject of law is the one who has a specific right, that is, the one to whom the provisions of objective law provide for the possibility of certain behavior. The subject of relationship is the one who has a specific right that is legally associated with another participant(s) of public relations who are entrusted with the responsibilities that correspond to the rights of the authorized person (Kharytonov \& Kharytonova, 2008, p. 21-22).

Indeed, this approach seems to be fair and can be illustrated by the following example of property relations: for example, the owner, since he has the power to own, use and dispose of his property, is, of course, a party to the property relationship, but in some cases, for example, when his property is pledged, the owner can no longer participate in the legal relationship, although he continues to be the subject of ownership (Razuvayev, 2007, p. 58-59). It can be noted that the concept of "subject of property rights" can be used to refer to all potential participants in the legal relationship, while the concept of "subject of legal relationship" is more appropriate to refer to owners who are in a specific legal relationship (however, it should be recognized that, since property relations are absolute, in most cases they will identify the subject of the law and the subject of the relationship, since the owner is usually in a state of steady and constant participation in the relationship) (Zhilnikova, 2011, p. 74-77).

Returning to the definition of subjects of legal relationships under the modern Ukrainian legislation, we should note that in accordance with Art. 2 of the Civil Code of Ukraine, members of civil relations are individuals and legal entities, the state of Ukraine, the Autonomous Republic of Crimea, territorial communities, foreign states and other subjects of public law. Here we have to mention that with respect to the right of private property, the circle of participants is limited and excludes subjects of public law. Thus, according to Art. 325 of the Civil Code of Ukraine, the subjects of private property are individuals and legal entities.

Therefore, to date, private property entities can only be natural persons, i.e. citizens of Ukraine, foreign nationals and stateless persons, who have equal rights, unless otherwise provided by law, which is consistent with the principle of equality of property right subjects enshrined in Art. 319 of the Civil Code of Ukraine, as well as legal entities, irrespective of their organizational and legal form, both domestic and foreign or joint, however, only legal entities of private ownership, i.e. subjects of private ownership may not be legal entities of public law. 
However, in an information society context, there are grounds for expanding the range of private property entities at the expense of new subjects of civil relations, whose legal status has not yet been determined, but denying the reality of existence or the apparent likelihood of which is no longer possible. Such a new subject of civil relations could potentially be an artificial intelligence.

As it was mentioned earlier, today there are many discussions on the possibility to qualify artificial intelligence as a potential subject of legal relationships. Thus, Kleinberg, Ludwig, Mullainathant and Sunstein (2019), in their research mention, that «algorithms have extraordinary promise. They have the potential to make important strides in combating discrimination, at least as the legal system has long understood it».

Sunstein (2001) analyzing the possibility of a computer program to be engaged in legal reasoning states that it cannot be yet. However, the scholar sees the possibility to recognize the subjectivity of artificial intelligence in the future.

Indeed, today there are many legal constructions that have subjectivity not being individuals with their own will, such as legal entities, state so on. It is a classic approach known as legal fiction. So why not give such subjectivity to artificial intelligence, robots, algorithms and alike in case such phenomena have certain features which give them the possibility to participate in legal relationships.

\section{ARTIFICIAL INTELLIGENCE AS A POTENTIAL SUBJECT OF PROPERTY RELATIONS}

Nowadays, the possibility to recognize the legal capacity of artificial intelligence is widely discussed (Čerka, Grigienè \& Sirbikytëb, 2017; Kamyshansky, Rudenko, Kolominetz \& Osadchenko, 2019). In case the legal capacity of artificial intelligence is admitted, the question will arise whether it has rights similar to those of an individual (Gadzhiev \& Voinikanis, 2018). Among these rights, the property right is of interest. Is it possible for artificial intelligence to own some property, use it for its own benefit and dispose of it? In this chapter, we are making an attempt to analyze possible scenarios.

It should be noted that not every artificial intelligence can potentially be considered a legal entity. To date, scholars distinguish three types of artificial intelligence. Weak or applied artificial intelligence (Narrow AI) is capable of solving only one or more tasks that can be performed by humans. Strong or general artificial intelligence (General AI) is focused on solving 
all the tasks that can be performed by humans. Artificial superintelligence is considered to be much smarter than human intelligence in almost every field. It is believed that artificial superintelligence can have even consciousness and subjective experiences.

Being integrated with technical systems, actuators and sensors, artificial intelligence is embodied in "robots", which, depending on the variety of artificial intelligence underlying them, are also divided into three groups: simple robots, android robots, androids. It is believed that only the androids can have a complete set of human cognitive functions and possess feelings, emotions, experiences and consciousness, and therefore be able to be a separate subject in relations with humans and other robots (Baranov, 2017, p. 18-40). That is, a potential subject of civil relations may be a robot integrated with general artificial intelligence, able to solve complex intellectual problems independently.

The European Parliament has already adopted a European Parliament resolution of 16 February 2017 with recommendations to the Commission on Civil Law Rules on Robotics (2015/2013 (INL)) (hereinafter referred to as the Resolution). The Resolution contains proposals to the European Commission to create

«a specific legal status for robots in the long run, so that at least the most sophisticated autonomous robots could be established as having the status of electronic persons responsible for making good any damage they may cause, and possibly applying electronic personality to cases where robots make autonomous decisions or otherwise interact with third parties independently" (European Parliament, 2017).

Legislators and researchers today are mostly focused on the problem of compensation for damage caused by artificial intelligence (Nekit, Kolodin \& Fedorov, 2020). Indeed, in connection with the commissioning of unmanned vehicles, this issue is of particular importance (in fact, most of the provisions of the Resolution are devoted to it).

Among the means of providing compensation for damage caused by artificial intelligence, the possibility of insurance of the risk of harming third parties by robots is discussed (in particular, in the Resolution) (Koval, 2017). However, when it comes to imposing certain responsibilities on robots, the rights that such electronic personalities should be empowered cannot be overlooked. In particular, in the context of liability insurance for damages, an interesting question arises - at whose expense such damage should be compensated? The answer to this question will depend on whether the robots have the property right. 
Thus, in case the robots are entitled to own property, an insurance fund may be formed at the expense of that property. And even if such a fund is not formed, it will remain possible to recourse to property of the owner for the damage caused by him on a general basis (Article 1166 of the Civil Code of Ukraine).

However, another question arises: does the robot require its own property? And will it not be necessary to control the use of this property? To answer that question some scholars appeal to the status of slaves in Roman private law. As it is known, slaves in the Roman private law were considered objects, not subjects of relationships. Nevertheless, they still got the possibility to have some property in terms of a special institution called peculium (Gamauf, 2009). However, in spite of the fact that sometimes there are parallels between the recognition of legal personality for robots and the recognition of legal personality for slaves, which once seemed impossible and later became natural (Karchevsky, 2017, p. 93-99), slaves were the same people yet. Unlike are robots which will always remain machines and it is difficult to imagine their uncontrolled functioning (that can be proved by the fact that the Resolution provides for the obligation for robot developers to integrate an emergency switch into the mechanism for their immediate shutdown in emergencies) (Koval, 2017).

Nowadays, some scholars propose to create status of electronic person by analogy with the status of a legal entity. Thus, a draft law to improve legal regulation in the field of robotics has been developed recently in Russia. The draft law proposed to add a new Chapter in the Civil Code of the Russian Federation, named "Robot Agents". It was planned to place this chapter in the section "Persons", that is, the robot was proposed to consider a subject of civil relations. The robot-agent is understood as a robot intended to participate in the civil turnover by the decision of the owner and by virtue of its design features. The robot-agent, according to the drafters of the law, has all the characteristics of a legal entity, except organizational unity, that is, it has separate property, acts on its own behalf and is liable for its own actions.

However, legal entities are considered to be subjects only because humans with their will and consciousness are involved in the activities of such entities. As for robots, it is assumed that they have their own will and consciousness, which allows them to take part in civil turnover without any human intervention. At the same time, the status of the robot-agents is reminiscent of the theory of "targeted property", which was used to explain the nature of the legal entity (Ivanov, 2017).

Most interesting in the context of our study is the question of the right to property belonging to the robot-agent. The following options are proposed 
to solve this issue (taking into account the fact that the robot-agent according to the aforementioned draft law is considered to be a subject and object of civil relations at the same time). The first option: the owner has the right to the robot-agent but not to its property, the latter belongs only to the robotagent. The second option: the owner has the right to both the robot-agent and its property, while the robot-agent has a limited proprietary right to its property. The third option: the owner has the right to both the robot agent and its property, and the robot agent is considered to be the owner of its property.

The main purpose of the aforementioned draft law is to limit the liability of the owner for the actions of the robot. Therefore, the draft law stipulates that the possessor and the owner of the robot-agent are responsible for the latter's actions only within the property that was transferred to the possession of the robot, i.e., the robot's debts could only be paid at the expense of its own property. The property of its owner, which was not transferred in robot's possession, is protected against the claims of creditors (Ivanov, 2017). Leaving aside criticism of the draft law regarding the doubling and tripling of titles to the robot-agent and its property, we may point out the rational grain in those proposals.

It should be noted that, the limitation of responsibility of the robot's owner by transferring of some property to the robot reminds in a way an institution called peculium, known to the Roman private law. Under Roman law pater familias could transfer to a slave some property for his benefit, and the liability for the slave's actions was limited to the value of such property. In modern Ukrainian civil law, similar situation is regulated by the provisions of fiduciary property. Thus, it is quite possible to apply the provisions on the status of fiduciary owner to relations involving robots. In this case, the property transferred to the robot can belong to it on the fiduciary property right. Such property should be created with a certain aim. The purposes set out in the contract for the transfer of property into a fiduciary property may also include certain needs for the maintenance of the robot itself. At the same time, the owner will remain able to control the use of property by the robot, and the liability for its actions will be limited by the size of this property. It is also possible a part of this property to be used for the special insurance fund, which would cover the damage caused by the robot to third parties.

But many more issues related to property rights of robots have to be resolved. For instance, an interesting case occurred when Columbus America claimed title to the property that was on the sunken ship S.S. Central America. The peculiarity of the case was that the court had to decide whether the boat and the treasures that had been found with the help of a 
remote-controlled device were those found by the person (the plaintiff) (Karchevsky, 2017, p. 94-95).In that case, the court recognized the plaintiff's rights to the property found. However, if the robots are given the opportunity to acquire ownership, the question of the acquisition of ownership in such cases will require some new decisions.

One more issue to be solved in connection with the constant development of information technologies, is related to the concept of transhumanism (the concept of infinite improvement of the human body through scientific and technical achievements, the creation of a "post human", the idea of cyborgization of people) (Katasonov, 2014). It would be necessary to determine also the legal status of such cyborgs - with the human brain copied / embedded in the machine (for example, in case of the failure of the human body due to age, disease, etc.). The questions of property that arise in such cases will concern not only the determination of the legal personality of such a being, but also the problems of determining the share of property that belonged to the person who turned into a cyborg. It must be decided whether such property will be transferred to heirs of such a person, or remain in the possession of a cyborg who would be recognized as a legal entity. There would also be a necessity to define the fate of the property which is stored for cyborg, but there are several copies of a person created. The question arises whether there should be the right of joint ownership, for example, or if that is not the case, how such property should be shared between copies. Probably, it is too early to talk about such issues today, but we should be ready for them also.

\section{THE POTENTIAL OF ARTIFICIAL INTELLIGENCE TO BE A SUBJECT OF INTELLECTUAL PROPERTY RELATIONS}

The intensive development of artificial intelligence has led to the fact that artificial intelligence systems have become capable of creating textual, musical, artistic, and visual works. The original works of the artificial intelligence system have already been presented to the public. These include works of famous writers, composers, artists, reworked by artificial intelligence as well as brand new works (Morkhat, 2018).

Back in 1959, the Soviet mathematician and programmer Zaripov, created the first program for the generation of musical works. The mathematician thought about the idea of an automated way of writing music while studying at a music school but started creating it only in graduate school (Zaripov, 1971). 
Currently, Facebook is developing artificial intelligence capable of converting music from one genre to another, using different musical instruments. For example, it is capable of turning a record of a symphony orchestra performing Bach into a piano performing (Ivanov, 2018).

In 2016, a group of museums and researchers from the Netherlands presented a portrait entitled "The Next Rembrandt" generated by a program that analyzed Rembrandt's works.

A short novel written by a Japanese computer program in 2016 went into the second round of a national literary award.

Google is funding the development of an artificial intelligence program that will write local news articles.

The Deep Mind Company owned by Google, has created software that can generate music by listening to recordings (Bridy, 2016).

The issue of establishing the authorship of code-generated works was raised by the U. S. Copyright Office back in 1965. There was discussed the issue of recognizing a computer as a tool in the creation of a work as well as a possibility to recognize authorship in a work generated by a program, without human intervention.

In 1974, the issue of authorship on generated works was again raised by the National Commission for the Technological Application of New Copyrighted Works in the U. S. Congress, and it was recognized premature to amend the legislation due to the lack of artificial intelligence capable of independently generating works of art. A comparison was made of the analytical mechanism created by Lovelace, the first female mathematician who participated in the development of the first algorithmic machine with a camera, a printing machine, which remains an inert tool, capable of functioning only with human assistance (Bridy, 2012).

Ten years later, in 1986, the issue of algorithmic creativity arose again in the U. S. Congress, where the report called into question that a computer was only an inert tool, unable to participate in the creation of works. In ten years from 1974 and 1986, the revolution of personal computers began, technologies began to create abstracts of articles autonomously, convert existing musical works into new compositions, edit images, and questions began to arise about property rights to computer-generated works. A 1986 report noted that an individual's creativity merges with a computer, blurring the differences between copyrighted works and computer-generated works. The authors of the report claimed that the expression of the programmer ends when the technology begins to be used by the user, and the situation becomes more complicated when the program makes its own choice independently of the programmer and the user. 
The idea that computer users are the sole authors of computergenerated works (and sole copyright holders of such works) has not been so obvious to the Commission in decades.

A 1976 report suggested that interactive computer programs could be recognized as co-authors of generated works, but there was no clear understanding who should be considered as co-authors, should it be programmers, users, or both, and who should be recognized as an author of a computer-generated work.

In the early 1980s, questions arose about the copyright of electronic video archives and their audiovisual displays. A number of courts have argued that it does not matter whether the displays are generated autonomously by a computer or by user action; in any case, the display is protected solely by the copyright on the game code.

Thus, since the 1970s, computers have been producing raw works, most of which are based on the creative input of a programmer, and can be compared to a tool such as a brush and a canvas. In this way, computers continue to replace individuals in various fields of activity, enhancing their functionality.

A computer program designed for machine learning purposes has a built-in algorithm that allows it to learn from the data entered, as well as to develop and make future decisions that may be pre-directed or independent. When applied to the arts, music, and literature, machine learning algorithms also learn from data provided by programmers. The algorithm examines downloaded data to create a new work, make an independent decision throughout the process to determine what the new work should look like. A feature of this type of artificial intelligence is that although programmers can set parameters, a work is actually generated by a computer program called a neural network in a process similar to a person's mental activity.

We should mention here the fact that European systems make a distinction between droits d'auteur and related rights. Both of these groups have similar exploitation rights, but moral rights are reserved to the author (and to some extent the artists). At the same time, under the U. S. system no distinction is made between droits d'auteur and related rights. Creative works and productions are all encompassed under the concept of copyright, which provides to the holder the right to make or to authorize third parties to exercise powers similar to those accorded under the exploitation rights of the European systems with only certain of their moral rights (attribution and integrity of the work) having been admitted recently for visual artists (Enrich, 2015). About authorship, the Ukrainian legislation follows common for European systems rules. 
Unlike the U. S. law, which does not require a claim for authorship of a person only, Art. 1 of the Law of Ukraine "On Copyright and Related Rights" recognizes as the author only natural person who created the work.

According to Art. 435 of the Civil Code of Ukraine and Art. 7 of the Law of Ukraine "On Copyright and Related Rights" the primary subject of copyright is the author of the work, that is, the natural person is indicated in the usual way as the author on the original or a copy of the work, in the absence of evidence of another.

The range of copyright entities in Ukraine is governed by specific legislation. In addition to authors of works that are the primary subjects of copyright, Art. 7 of the Law "On Copyright and Related Rights" refers to them the heirs and persons to whom the authors or their heirs have transferred their copyrights, that is, derivative entities that acquire property rights to the work under the law or the contract. Consequently, the term "copyright subject" is much broader than the term "author of a work". As Nikitina (1972) points out, the subject of copyright is the person who owns the copyright in whole or in part.

Both natural and legal persons may be subject to copyright, while only natural persons may be considered as authors of the work. In this regard, D. Liptsik (2002) notes that only individuals are capable of creating intellectual works, since only a person is capable of learning, thinking, evaluating, creating literary, musical and other works of art.

Thus, to create a work, and therefore to be the author, can any human regardless of gender, age, nationality, citizenship, etc. Analyzing the historical development of copyright and its current state, we can see that there are many cases where very young people create highly artistic works, and therefore, they are subject to all the rules governing copyright.

In the context of the problem of copyright recognition for artificial intelligence, the issue of copyright for translations is of interest. According to Art. 20 of the Law of Ukraine "On Copyright and Related Rights", translators and authors of other derivative works are entitled to copyright for their translation, adaptation, arrangement or other alteration. Translators and/or authors of other derivative works enjoy the copyright of the work they have created, provided they respect the rights of the author whose work has undergone translation, adaptation, arrangement or other alteration. The copyright of translators and / or authors of other derivative works does not prevent other persons from performing their own translations and reproductions of the same works.

Therefore, literary translation is considered to be a separate work, which is granted legal protection, and at the same time raises the question of the possibility of protecting the results of machine translation, and the case 
of editing such a translation, even in a small part, by a person. Given that neither the author of the program (tool) nor the program itself contributes creatively to the final result, it can be assumed that as the author should be recognized only its operator, the user who set up the system to create a specific object.

Following the formal logic, the copyright holder of the work independently generated by the software is the author of the software. At the same time, if you follow this logic, the process of creating works will be missed, and this will not be true, even if it fills a gap that is not yet regulated by copyright (Bridy, 2012).

According to the executives of the Japanese advertising and communications holding Dentsu Inc., modern technologies allow copywriters to write up to 100 texts in five minutes. In this case, the algorithm does not replace the copywriter, the robot will not be able to create all advertising without human assistance. Its mission is to help employees reach new heights by increasing their productivity.

Nowadays, modern computers are capable of solving many intellectual tasks that have traditionally been considered creative and subject only to human thinking.

An expression of support for human indispensability in the field of creativity can be found in philosophical studies. Thus, Pushkarev (2014) notes that the capabilities of the algorithm, which has many advantages over natural thinking, are limited in the area where creativity occurs, the creation of a fundamentally new, especially a work of art.

The main question discussed is whether artificial intelligence can have self-awareness. So far, the development of artificial intelligence technology has not achieved this, and there is no evidence that it can actually be achieved in the future. This question is relevant given that a subject who feels or is in any way aware has the moral right to have an appropriate legal status (Pavlovskaya, 2018).

The American scholar, Bryde (2012), suggests that programs, including those characterized by the capacity for self-development and learning, have not yet become a separate category of authors of intellectual outputs, not because of the technical complexity of their creation and dissemination, but because there is no legal basis for this.

As long as the generated works are of mechanical origin, being the result of data processing, the program is indirectly related to human authorship and creativity. It matters when the generated works can be mistakenly taken as the result of human creativity, so there is a temptation to attribute authorship to humans. Therefore, as long as artificial intelligence 
lacks self-awareness, is not aware of the emergence of intellectual rights, existing relationships can be regulated by available means.

Russian scientist Morkhat conducted a thorough research into the understanding of civil law regulation of artificial intelligence in his work "The Legal Entity of Artificial Intelligence in the Field of Intellectual Property Rights: Civil Legal Problems". The scientist acknowledges that artificial intelligence cannot be compared to the full extent of man, as it lacks the soul, consciousness, feelings, interests, and free will. At the same time, the scientist believes that in the legal aspect consciousness is not a necessary or sufficient condition for legal personality. On the one hand, sometimes fully conscious individuals such as children, slaves in Roman law, are deprived of full legal personality. On the other hand, temporarily unconscious people, such as when they are in a coma or while sleeping, are not deprived of their legal personality only on this basis, although in some cases they cannot exercise most of their rights. Similarly, legal entities are not conscious, but still they have legal personality (Morkhat, 2018).

Nowadays, society is in the process of a technological revolution that may need to rethink the interaction between computers and creativity. The revolution is underpinned by rapid software development, the creation of autonomous systems, artificial intelligence capable of learning without being specially programmed by a person (Guadamuz, 2017).

According to the concept of Morkhat (2017), the legal personality of artificial intelligence should be a kind of "floating" depending on the type of intelligence, its initial or current functional purpose. According to the scientist, the legal status can vary from the simple form, which is expressed in the legal position of such artificial intelligence solely as a human instrument, to the cases of giving artificial intelligence legal personality of "electronic person" and further, to full legal personality of artificial intelligence. For example, in the case of artificial intelligence in the absence of human crew in outer space, on other planets (to avoid risks to humans). This approach, according to the scientist, should be the basis of legal definitions while defining a legal personality of "electronic person".

The scientist proposes the following possible variants of the regimes for the legal regulation of intellectual property rights for the results of intellectual activity, created with the substantial participation of artificial intelligence or fully autonomously generated by the program: (i) complete refusal to grant artificial intelligence any intellectual property rights (consideration of artificial intelligence as a tool); (ii) giving artificial intelligence the legal status of a social agent without granting him any intellectual property rights (accordingly, all works created by such a program or with its participation are automatically transferred to the public 
use); (iii) consideration of generated works of artificial intelligence as works-made-for-hire; (iv) hybrid assignment of intellectual property rights to both the program (artificial intelligence) and the human being, with the division of rights between them; and, (v) giving artificial intelligence a certain amount of intellectual property rights.

It seems to be a great idea the one proposed by Pearlman (2018), according to which

«the law and court should (1) recognize sufficiently creative Als as authors and inventors matched with (2) Al IP rights assignment to natural or legal persons (i.e., business or government entities). First, the law must put in place a test to determine if or when an $\mathrm{Al}$ might be granted such a status. Second, in such a case, the law must put in place an assignment regime that recognizes ownership by the appropriate party, including default rules and conditions of assignment».

According to Morkhat (2018), the personality of an "electronic person" can be implemented in the long term with respect to a limited range of complex robotic artificial intelligence systems.

The rapid growth and development of autonomous systems and algorithms in different spheres of society should be acknowledged, indicating that humanity is moving gradually into an era in which the program will be able to relatively autonomously generate works that are indistinguishable from the results of human creativity.

\section{Conclusions}

1. It is becoming increasingly probable that legal personality will be recognized for artificial intelligence. However, legal personality can only be recognized for the so-called "strong" artificial intelligence or superintelligence, which will have self-awareness and will be capable of making decisions based on personal experience. In addition, it is assumed that superintelligence will have its own subjective experiences.

2. Giving subjectivity to artificial intelligence, robots, algorithms and alike in case such phenomena have certain features which give them the possibility to participate in legal relationships does not contradict the classical approach according to which legal fictions exist in legal reality.

3 . The recognition of legal personality of artificial intelligence will entail the emergence of a new subject in civilian relations. It is necessary to develop the status of such a subject, taking into account its specificity.

4. According to the most popular conceptions, it is proposed to recognize the legal personality of artificial intelligence by analogy with slaves in Roman law or with legal entities. 
5. Recognition of artificial intelligence as the subject of legal relations will entail recognition of certain rights, including property rights and the rights to the results of intellectual work created by it.

6. In property relations, it is proposed to recognize the possibility of endowing artificial intelligence with a particular property. With this property, artificial intelligence will be liable for its obligations. This will simplify the resolution of the issue of liability for harm caused by artificial intelligence.

7. Until the issue of granting robots the rights in full is resolved, certain property can be transferred to artificial intelligence on a trust basis. In this situation, a special subject arises, the so-called robot-agent, who can conduct some business of its owner. This will limit the liability of the owner of the robot for obligations created by the robot by property transferred to trust.

8. Concerning the objects of creativity created by artificial intelligence, it is concluded that it is possible to recognize intellectual property rights to the results of the work of artificial intelligence recognized as an "electronic personality". This will be permissible in cases where such works are created entirely by artificial intelligence, without human intervention.

\section{REFERENCES}

Alekseev, S. (1981). General theory of law. Moscow: Legal Literature.

Baranov, O. (2017). The Internet of Things and Artificial Intelligence: Origins of the Problem of Legal Regulation. In IT Law: Problems and Prospects for Development in Ukraine. Lviv: National University of Lviv Polytechnic.

Borysova, V., Spasybo-Fateyeva, I., \& Yarotsky V. (2007). Civil law of Ukraine. Kyiv: Yurinkom Inter.

Bridy, A. (2016). The Evolution of authorship: work made by code. Columbia Journal of Law \& Arts, 39, 395-401.

Čerka, P., Grigienè, J. \& Sirbikytèb G. (2017). Is it possible to grant legal personality to artificial intelligence software systems? Computer Law \& Security Review, 33 (5), 685-699.

Duarenus, F. (1554). "Epistola ad Andream Guillartum de ratione docendi, discendique iuris conscripta". In Opera Omnia. Lugduni.

Enrich, E. (2015). Continental European (droit d'auteur) and anglo-saxon (copyright) systems of copyright and performing rights organizations in Europe and the USA. Retrieved from https://www.academia.edu/10300580/CONTINENTAL_EUROPEAN_droit_da uteur_AND_ANGLO- 
SAXON_copyright_SYSTEMS_OF_COPYRIGHT_AND_PERFORMING_RI GHTS_ORGANISATIONS_IN_EUROPE_AND_THE_USA.

European Commission (2020). On Artificial Intelligence - A European approach to excellence and trust. White Paper. Retrieved from https://ec.europa.eu/info/sites/info/files/commission-white-paper-artificialintelligence-feb2020_en.pdf

European Parliament (2017). Resolution of 16 February 2017 with recommendations to the Commission on Civil Law Rules on Robotics (2015/2103(INL)). Retrieved from http://www.europarl.europa.eu/sides/getDoc.do?pubRef=//EP//TEXT+TA+P8TA-2017-0051+0+DOC+XML+V0//EN.

Gadzhiev, G. \& Voinikanis, E. (2018). Could Robot be a Legal Subject? (In Search of Legal Forms for Digital Economy Regulation). Pravo - Zhurnal Vysshei Shkoly Ekonomiki, 4, 24-48.

Gamauf, R. (2009). Slaves doing business: the role of Roman law in the economy of a Roman household. European Review of History: Revue européenne d'histoire, 16(3), 331-346.

Guadamuz, A. (2017). Artificial intelligence and copyright. WIPO Magazine, 5. Retrieved from https://www.wipo.int/wipo_magazine/en/2017/05/article_0003.html

Halphina, R. (1974). General doctrine of legal relationship. Moscow: Legal literature.

Heise, A. \& Cropp, F. (1827). Juristische Abhandlungen mit Entscheidungen des Oberappellationsgerichts der vier freien Städte Deutschlands. Hamburg: Perthes.

Ivanov, A. (2017). Do androids dream about electric sheep? Retrieved from https://zakon.ru/blog/2017/2/15/mechtayut_li_androidy_ob_elektroovcah

Ivanov, S. (2018). Facebook introduced artificial intelligence that can turn any track into a symphony. Retrieved from https://hightech.fm/2018/05/24/facebook

Kamyshansky, V., Rudenko, E., Kolominetz, E. \& Osadchenko, E. (2019). Regarding the issue of the essence of legal treatment and the possibility of granting legal status to a robot in Civil Law. In E. Popkova (eds.), Ubiquitous Computing and the Internet of Things. Studies in Computational Intelligence, 826, 299-306.

Karchevsky, M. (2017). Basic Problems of Legal Regulation of Artificial Intelligence Socialization. In: IT Law: Problems and Prospects for Development in Ukraine. Lviv: National University of Lviv Polytechnic.

Katasonov, V. (2014). Transhumanism: a new civilization threat to humanity. Retrieved from https://riss.ru/analitycs/6613

Kharytonov, E. \& Kharytonova O. (2017). IT law: theory and practice. Odesa: Fenix.

Kharytonov, E., \& Kharytonova, O. (2008). Civil legal relationships. Kyiv: Istyna.

Kleinberg, J., Ludwig, J., Mullainathant, S. \& Sunstein, C. R. (2019). Discrimination in the age of algorithms. Journal of Legal Analysis, 10, 1-62. 
Kokhanovska, O. (2006). Theoretical issues of informational relationships in civil law. Kyiv: Kyiv University.

Koval, M. (2017). Electronic personality: why the EU discusses the rights of robots. Retrieved from https://www.eurointegration.com.ua/experts/2017/01/24/7060539/.

Kutateladze, O. \& Zubar, V. (2011). Savigny F.K. System of modern Roman law. Moscow: Statut.

Liptsik, D. (2002). Copyright and Related Rights. Moscow: Ladomir Unesco Publishing House.

Marushak, A. (2011). Definition of the concept "informational human rights". Information and Law, 2, 21-26.

Matuzov, N. \& Malko, A. (2004). Theory of State and Law. Moscow: Publishing house "Lawyer".

Morkhat, P. (2018). Intelligent robot as the author of a work or invention. Legislation and law, 8, 172-177.

Nekit, K., Kolodin, D. \& Fedorov, V. (2020). Personal data protection and liability for damage in the field of the Internet of things. Juridical Tribune, 10(1), 80-93.

Nikitina, M. (1972). Copyright on works of science, literature and art. Kazan: Kazan Publishing House.

Pavlovskaya, Y. (2018). "A robot cannot have self-awareness": interview with the creator of an android who works at an insurance company. Retrieved from https://vc.ru/future/48827-u-robota-ne-mozhet-byt-samosoznaniya-intervyu-ssozdatelnicey-androida-kotoryy-rabotaet-v-strahovoy-kompanii

Pearlman, R. (2018). Recognizing artificial intelligence (AI) as authors and inventors under U.S. Intellectual Property Law. Richmond Journal of Law \& Technology, 24(2), i-38.

Pushkarev, A. (2014). Creativity and Artificial Intelligence: A Problem Statement. Humanities, socio-economic and social sciences, 12-1, 93-96.

Razuvayev, I. (2007). Theoretical issues of general doctrine of the subjects of law. Legal Thought, 3, 58-59.

Saveliev, V. \& Kofanova, 1. (1997). Guy. Institutions. Moscow: Lawyer, 1997.

Shpenov, D. (2011). Subjects of legal relationships in the information sphere. Visnyk of the Kyiv University of Taras Shevchenko: Legal Sciences, 89, 92-95.

Sunstein, C. R. (2001). Of artificial intelligence adn legal reasoning. University of Chicago Law School Roundtable, 8(1), 29-36.

Zaripov, R. (1971). Cybernetics and music. Moscow: Publishing house "Knowledge”.

Zhilnikova, E. (2011). Problems of differentiation of concepts "subject of law" and "subject of legal relations". Historical, philosophical, political and legal sciences, cultural studies and art criticism. Questions of theory and practice, 7 (13), 74-77. 